\title{
Analysis of Risk Assessment on Stock System Services using COBIT 5 Framework
}

\author{
Indriyanto \\ Department of Information System Universitas \\ Ahmad Dahlan \\ Yogyakarta of Indonesia
}

\author{
Imam Riadi \\ Department of Information System Universitas \\ Ahmad Dahlan \\ Yogyakarta of Indonesia
}

\begin{abstract}
Information System is Canasoft dedicated to provide the best service in terms of stock goods services. SIM Canasoft can be accessed through the relevant agency under study.information Canasoft systems allow for risks that could interfere with information assets and data assets. This study uses the framework COBIT 5 which aims to analyze risk assessment so that organizations can choose a mitigation approach to risks that may occur and provide recommendations. This research was conducted with a COBIT 5 risk assessment guide that focuses on two domains, namely the APO12 domainAPO12 (Rist Management)(Rist Management) and thedomain. EDM03 (Ensure Rist Optimization) by covering the stages of data collection, risk analysis, risk profile, articulating risk, risk tolerance value and how to respond to risk. The research method uses quantitative analysis. Data obtained using questionnaires, direct observation and interviews were calculated using the Guttman method. The RACI Chart supports in determining the appropriate respondents. The results of the study show that thevalue Capability level in the APO12 domain is 2.60 and EDM03 is 2.58 , meaning that at this level the implementation of business processes in information system services Canasoft's has carried out planning, monitoring and adjustment and the work results have been determined, observed and maintained properly. APO12 has avalue Gap of 1 level, this is the basis for making recommendations. While EDM03 also has abasis for Gap of 1 level, this is the making recommendations. This research has been carried out well in accordance with the expected research objectives.
\end{abstract}

\section{Keywords}

Risk assessment, Canasoft Information System Services, RACI chart Cobit 5 .

\section{INTRODUCTION}

Use of technology is certainly closely related to all aspects of life, this reason is evidenced by the existence of technology that really helps humans to carry out their daily needs. One of them is in the aspect of utilizing technology, namely information technology services that provide services for both data and information needed by companies and organizations that use information technology services in various sectors to be able to become a bridge in achieving common goals.

Griya Cell Company is a company that trades cellphones, accessories, and others. Griya cell which is domiciled in the city of Yogyakarta, Sleman, Berbah Griya Cell in the management of stocking goods and in the data processing process already uses IT, namely the Information System Canasoft. Canasoft cell phones and accessories is an information system that is used for processing stock of goods, especially, this system presents various menus in which it presents submenus that function to stock goods containing Data, Purchases, Sales, Inventory of Goods, and others.

So from some of the background problems above, this research will have a title, namely "Analysis of Risk Assessment in Canasoft Information Systems Using the Cobit 5 Framework". The business processes carried out by canasoft do not yet have a risk management standard and can be considered as a common business process, in other words, all business processes that are carried out do not have risk benchmarks as the basis for carrying out business processes (sparely). Meanwhile, the APO12 and EDM03 domains are early stage domains used for risk management.

\section{LITERATURE STUDIES}

\subsection{Information Security}

Implementation of information security aims to overcome technical and non-technical problems and obstacles such as availability, confidentiality, and integrity so that the level of information security can be assessed [1].

\subsection{Definition of Risk}

Risk is an unpleasant (harmful/harmful) result of an action or action [4] the risk arises due to conditions of uncertainty, investment can bring profit (price goes up), can also cause loss (price goes down) [5]

\subsection{Type of Risk}

Classifying risk into two, namely pure risk and speculative risk. In addition, risk is also distinguished between dynamic risk and static risk arising from certain equilibrium conditions. Risk is also subjective and objective. [5] The description of the risk categories can be seen in Figure 1[5].

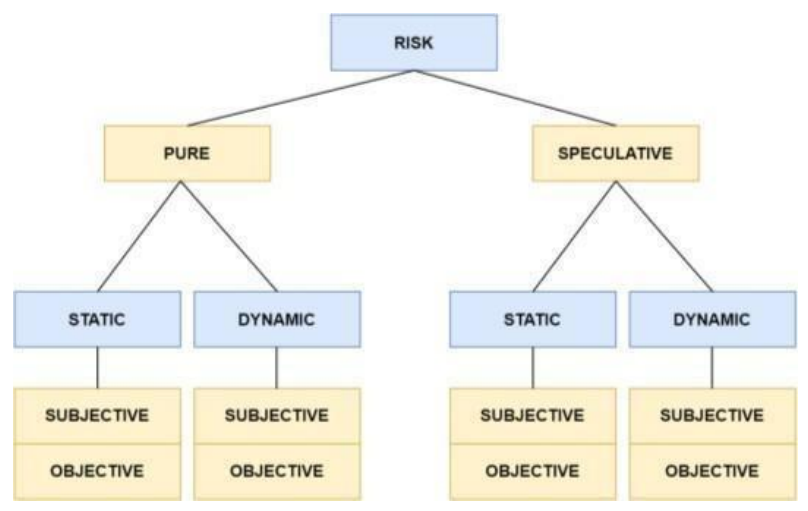

Figure 1. Type of Risk

\subsection{Risk}

Factors Factors that give rise to risk are disasters and hazards. Hazard classification can be divided into several types, 
namely physical, moral, moral, and legal or regulatory hazards. [6] While the classification of the causes of risk can be divided into several types, namely physical asset risk, employee risk, and legal risk, [7]

\subsection{Information}

System Audit Information System audit needs to be done to check information technology The level of readiness can be seen from governance, while the level of concern can be seen from all related parties regarding the position and direction to be addressed [5]

\subsection{Canasoft}

Canasoft Business Software is a simple accounting software that is very appropriate to use in the business climate and small and medium commerce. Currently Canasoft Business Software is used by most mobile business people. In addition to understanding and understanding the characteristics of the mobile business field, Canasoft Business Software also applies simple and effective concepts in managing the books and records of every day-to-day business transaction.

\subsection{Risk Management}

Methods Information technology risk management methods are frameworks designed to address various risks associated with the use of information technology[5]. Here are some references that will form the basis for creating the method. These methods include COBIT, OCTAVE, ITIL, NIST, and others.[4]

\subsubsection{COBIT 5 Method}

COBIT (Control Objectives for Information and Related Technology) is an IT governance framework and set of supporting tools that enables managers to bridge the gap between requirements control, technical issues and business risks. COBIT enables the development of clear policies and good practices for controlling IT across the organization (ISACA, 2012).[8]

\subsubsection{Implementation COBIT 5 (ISACA, 2012) Implementation COBIT 5}

ISACA(2012) how to implement COBIT 5 need to consider the following points:

1. That the parties who became the The main role in running the wheels of business processes that support change and create a desire to achieve goals which are then realized in the form of new processes, controllers can be sourced from internal and external parties as well as the existence of issues that enable them to become supporters of change drivers.

2. IT goals with enterprise strategy and risk are commensurate and prioritize key enterprise goals, IT goals and IT processes. Provide a reference and tolerance limit for awareness in other words an innuendo between the goal and the existing risk.

3. Set targets for improvement, which is then followed by gap analysis to identify relevant alternative solutions that are fast and profitable. Recommendations are derived based on the value of the known difference with the relevant calculation steps to determine the right recommendation.

4. Planning the right solution for immediate execution, monitoring, and ensuring ongoing business risks. The selection of the right alternative can be a major factor in the success of risk prevention so that the impact of these risks does not cause big losses for an organization or company.

5. Calculate and monitor the system to ensure the business does not change the direction of the goal which is then carried out with daily activities.

6. Focus on the revolution of the ongoing shift from improving management and management practices towards business and monitoring the achievement of improvements using performance schemes.

Evaluate achievement of objectives to identify governance needs and continuous improvement needs.

\subsubsection{Raci Chart}

The RACI method aims to determine respondents who comply with the rules of APO12 and EDM03. The RACI Organization chart is a tool to help determine decision making and assist organizations in identifying employee roles and responsibilities. aims to avoid overlapping positions that affect employee performance. Domain APO12 is a domain that is in COBIT 5, APO12 focuses on IT risk management. The 6 sub domains related to APO12 are:

1. APO12-01 (Collecting Data) The Domain contains official rules regarding the stages of technical data collection.

2. APO12-02 (Analyzing Risk) Domain contains rules related to technical IT risk analysis.

3. APO12-03 (Maintaining Risk Profile) Domain contains rules related to efforts to maintain assets in response to the impact of IT risks.

4. APO12-04 (Articulating Risk) Domain that contains technical rules for determining the appropriate response by stakeholders relevant.

5. APO12-05 (Reducing the impact of risk) The Domain contains rules to minimize the impact of IT risks.

6. APO12-06 (Responding to Risk) Domain that contains the rules of how to determine the right action after an IT risk occurs.

Below is the raci chart of APO12:

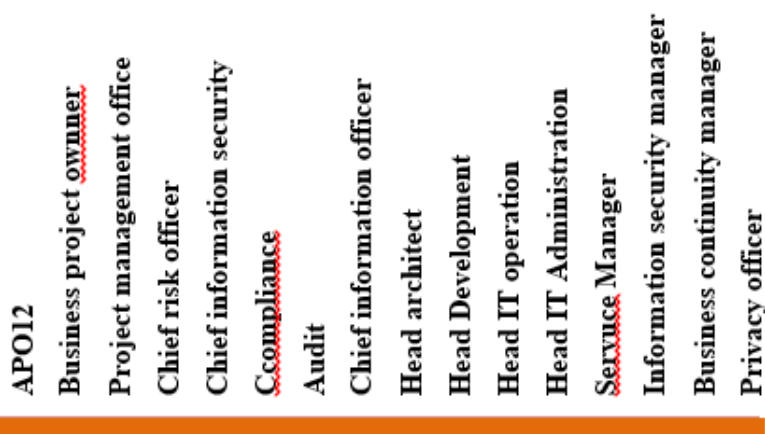

2 R C R C R R A C C C C C C C C

4 R C R C C C A C C C C C C C C

6 R R R R C C A R R R R R R R R

Figure 2. Raci Chart APO12 
Based on Figure 2[8]. Work units can be seen in the APO12 domain. RACI Chart or also known as Responsible, Accountable, Consulted, and Informed. The person in charge is the person who is responsible for driving the business wheel, the responsible actor who makes decisions, the Consultant who is in charge of providing direction and input on the business process and Informed is the actor who must know the final information of the chosen alternative.

\section{Processes that exist in the EDM03 domain:}

1. EDM03.01 Evaluating Risk Management This process aims to evaluate and make an assessment of the direct impact and long-term impact of the risk of using IT on the organization.

2. EDM03.02 Directing Risk Management This process aims to direct the implementation of risk management to ensure that IT risk management must be able to ensure that IT risks are not exceeds the growth risk of the organization

3. EDM03.03 Monitoring Risk Management This process aims to monitor the objectives and matrix of the risk management process and develop how IT risk issues are identified, tracked and reported. below is the RACI Chart EDM03:

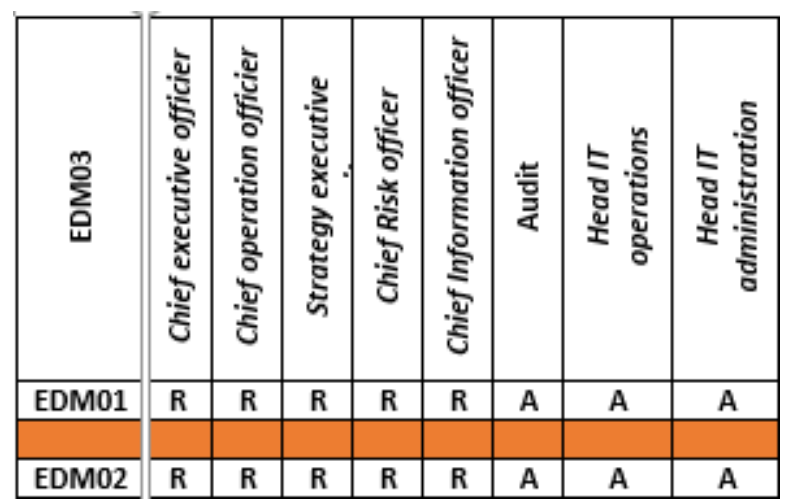

Figure 3. RACI Chart EDM03

Based on Figure 3[8]. The work unit can be seen in the EDM03 domain. RACI Chart or also known as Responsible, Accountable, Consulted, and Informed. The person in charge is the person who is responsible for driving the business wheel, the responsible actor who makes decisions, the Consultant who is in charge of providing direction and input on the business process and Informed is the actor who must know the final information of the chosen alternative

\subsubsection{Data Processing Respondents}

Data processing uses the Guttman calculation method using Microsoft Excel as a calculating tool. The calculation starts based on answers from 1 respondent in each APO12 and EDM03 domains. The calculation of the weight of the questionnaire value, if the value is [Y] then according to the Guttman Scale has a value of 1 , whereas if the value $[\mathrm{T}]$ has a value of 0 . The calculation is managed based on the respondents' answers in each domain. Processing of respondent data can be seen in Table 1[9]:

Table 1. Guttman Scale

rata-rata $: \frac{\text { Bobot Jawaban }}{\text { Jumlah Pertanyaan }}$
Normalisasi $: \frac{\text { Jumlah rata }- \text { rata Level }}{\text { Jumlah rata }- \text { rata seluruh Level }}$
Normalisasi Level $:$ Normalisasi $*$ Level

Calculation of the average, normality, and level normalization.

\subsubsection{Capability Level}

According to (ISACA, 2012) Measurement of the value of capability using the interview method to several experts in the scope of work at the Griya Cell Shop related to IT services. In the capability assessment, there are 6 (six) levels that must be considered as follows:

\section{Level 0 -Incomplete Process}

At this level the process is not implemented or fails to achieve the objectives, lack of evidence stating the achievement of the process objectives.

\section{Level 1-Performed Process}

The process that has been implemented has met or achieved the objectives which are then implemented.

\section{Level 2-Managed Process}

The process that has been carried out at the previous level, at this level the implementation of the process has been carried out with planning, supervision and adjustment and the work results have been determined, supervised and properly cared for.

\section{Level 3-Established Process}

At this stage the company has implemented IT processes and is well standardized

\section{Levil 4-Predictable Process}

This process the company has carried out the IT implementation process within the specified limits in order to achieve the expected results.

6. Level 5-Optimizing Process

At level 5 processes are continuously improved to meet current and projected organizational goals in the future.

\section{METHODOLOGY}

\subsection{Research Phase Research}

activity is a process of acquiring or acquiring knowledge to solve the problems systematically, and logically. In conducting research there are similarities in determining the stages of research, it's just that sometimes it needs to be adjusted to research needs.

This research will discuss the Risk Management Assessment of Information Technology Services in the information system Canasoft that have not implemented risk management on ongoing business processes following COBIT 5 standards. Objects will be focused on Information Technology Services using the COBIT 5 framework. A study will be able to be said to run if it has standards that will be taken until it reaches its expected final destination. This research will be referenced following the stages contained in COBIT 5 to carry out the research to be conducted.

The research phase that will be conducted in this study will be described with a flowchart as a reference step achieved until this research is considered complete. Stages from the early stage to the final stage as a limit of motion in conducting research.

This section will explain the methodology in conducting research, so that the work steps become more systematic and organized The research stages will be described in Figure 4: 


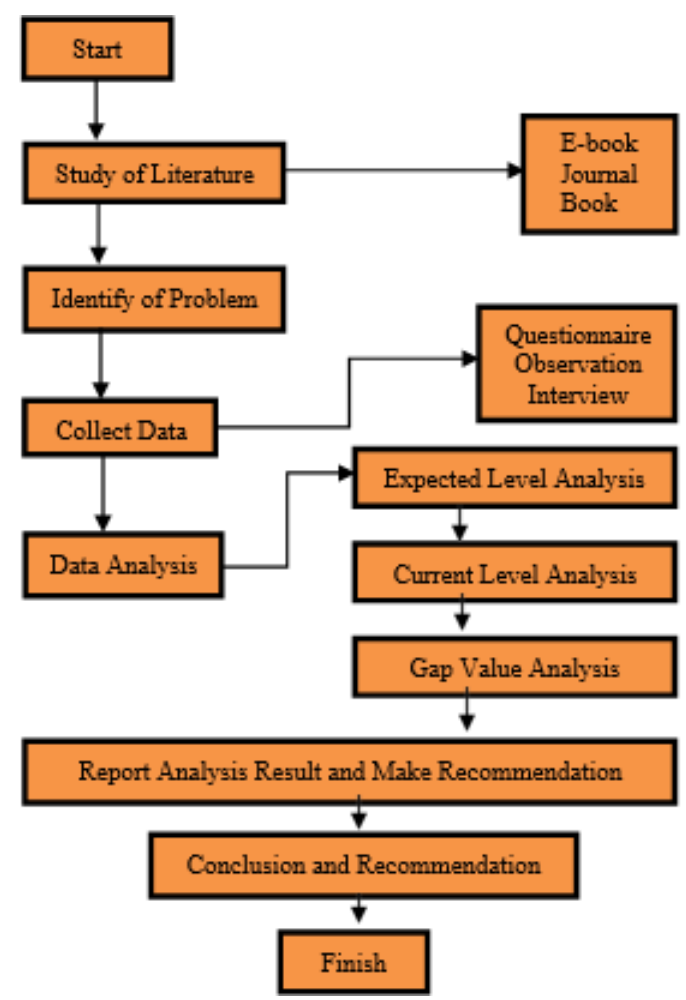

Figure 4. Research Steps Methodology

Stages the research stage includes 6 steps in outline as follows:

[1] The first stage the researcher will start research by conducting literature studies as an initial stage, literature studies are carried out by collecting references from both journals and books. There are 6 journals quoted, of course the journals used in research in the last 3 years and 1 book about COBIT 5.

[2] The second stage is identifying the problem, this stage the researcher makes direct observations in Human Resources in Higher Education to get results from these problems.

Synchronizing the problem with the method taken, namely COBIT 5 and position mapping using the RACI Chart method.

[3] The third stage is collecting data. Data collection techniques using the media Questionnaire, Observation, and Interview.

[4] The fourth stage performs data analysis. First, the researcher will assess the maturity value of the current capability level by processing the questionnaire data, then the researcher will assess the desired capability level maturity value and the last time the researcher conducts a gap assessment.

[5] In the fifth stage, researchers will make recommendations in accordance with each domain that has a gap value, the follow- up if the recommendations are implemented the organization will have the advantage of being able to reach the desired level. Recommendations will then be reported to human resources in universities as input to increase the desired level.

[6] The sixth stage, researchers will share suggestions and conclusions in conducting research based on known results.

\subsection{Tools and Materials}

Tools and materials used in this study are divided into two types, namely research support software in processing data and supporting hardware in conducting research tools and materials used to help researchers make it easier to conduct research so that they can achieve the desired goals. Research tools and materials are as shown in Table 2:

Table 2. Tools and Materials

\begin{tabular}{|l|l|}
\hline \multicolumn{1}{|c|}{ Software } & \multicolumn{1}{|c|}{ Hardware } \\
\hline $\begin{array}{l}\text { 1. Operating System } \\
\text { Windows 10 pro 64 bit }\end{array}$ & $\begin{array}{c}\text { 1. Processor AMD A9® } \\
\text { ATI RADEON 3.00 GHz }\end{array}$ \\
\hline $\begin{array}{l}\text { 2. Tools Microsoft Word and } \\
\text { Microsoft Excel 2013 }\end{array}$ & $\begin{array}{l}\text { 2. Random Access Memory } \\
4.00 \mathrm{~Gb}\end{array}$ \\
\hline $\begin{array}{l}\text { 3. Snipping tool and } \\
\text { Drawing.io }\end{array}$ & 3. Type memory SSD 256GB \\
\hline
\end{tabular}

Based on Table 2 are tools and materials used as supporting materials in conducting IT Risk Management research.

\subsection{Implementation}

\subsubsection{Data Collection}

The research method used is quantitative analysis method with data collection techniques using questionnaires, interviews, and observations.

\subsubsection{Questionnaire}

Respondents were determined using the RACI chart method, aiming for more precision and more accurate results. Researchers have distributed questionnaires to prospective respondents. Technically, the researcher accumulated data by using the RACI Chart method, which is a method that directly distinguishes work units based on Job descriptions of Stakeholders, so that the questionnaire will be valid.The results of mapp the RACI Chart can be seen in Table 3:

Table 3. Results of Mapping Respondents RACI Chart

\begin{tabular}{|c|l|c|c|}
\hline No. & \multicolumn{1}{|c|}{ Unit COBIT 5} & & ID \\
\hline 1. & Business process owner & & R5 \\
\hline 2. & Project Management Office & R1 \\
\hline 3. & Chief risk officer & R2 \\
\hline 4. & Chief information security officer & & R3 \\
\hline 5. & Head architect & R2 \\
\hline 6. & Head development & R4 \\
\hline 7. & Head IT operations & R3 \\
\hline 8. & Head IT administration & R3 \\
\hline 9. & Service Manager & R2 \\
\hline 10. & Information security manager & R3 \\
\hline 11. & Business continuity manager & R1 \\
\hline 12. & Privacy officer & R2 \\
\hline
\end{tabular}

ased on Table 3 above, the results of the mapping of the RACI Chart domain APO12 and EDM03 on the information system service Canasoft in Griya cell are 12 units, but there are people whose performance is doubled. The result is 5 respondents will be respondents in the questionnaire.

\subsubsection{Observation and Interview}

Aims to obtain valid data and information so that research results can be maintained to completion.

1. The expected Capability level value is 3 levels.

2. An overview of the business process organization of 
Information System Services Canasoft's at Griya cell has implemented IT risk management but is not up to the standard COBIT 5 and has full control over the system.

3. Finance and Assets is an external party that assists Canasoft's Information System Services at Griya cell to assist turnover.

4. SOP document regarding employee responsibilities and the use of the Canasoft system in Griya cell.

5. Canasoft's information system service at Griya cell has made a classification of IT risks against those that have occurred.

6. There is no effective benchmark to measure employee success.

7. Many IT-related business risks are identified but not documented in the form of a visible database, but only

\begin{tabular}{|c|l|c|}
\hline Domain & \multicolumn{1}{|c|}{ Process } & Current Level \\
\hline APO12.01 & Collecting Data & 2.70 \\
\hline APO12.02 & Analyzing Risk & 2.60 \\
\hline APO12.03 & Maintaining Risk Profile & 2.66 \\
\hline APO12.04 & Articulate Risk & 2.62 \\
\hline APO12.05 & Lowers risk impact & 2.72 \\
\hline APO12.06 & Respond to Risk & 2.29 \\
\hline
\end{tabular}

The current APO12 (Risk Management) Capability value is known through Guttman's calculation which has a value of 2.60 (Managed Process). the result is obtained by calculating the average of the known Current Level values in each APO12 (Risk Management) domain. Reaching a score of 2.60 means that the implementation of business processes on Canasoft's Information Systems Services at Griya cell has carried out planning, monitoring, and adjustments, and the work has been well organized, observed and maintained, but needs a little improvement to reach the desired level. The following are the results of the current EDM03 calculation in Table 5:

Table 5. Current EDM03 Calculation Results

\begin{tabular}{|c|l|c|}
\hline Domain & \multicolumn{1}{|c|}{ Process } & Current Level \\
\hline EDM03.01 & $\begin{array}{l}\text { Evaluating Risk } \\
\text { Management }\end{array}$ & 2.58 \\
\hline EDM03.02 & Directing Risk Management & 2.67 \\
\hline
\end{tabular}

The current EDM03 (Optimized Risk Management) Capability value is known through Guttman's calculation which has a value of 2.58 (Managed Process). the result is obtained by calculating the average of the known Current Level values in each APO12 (Risk Management) domain. Reaching a score of 2.58 means that the implementation of business processes on Canasoft's Information Systems Services at Griya cell has carried out planning, monitoring, and adjustments, and the work has been well organized, observed and maintained, but needs a little improvement to reach the desired level.

\subsubsection{Expected Capability Analysis}

The capability value desired by Canasoft Information System Services in Griya cell has 3 levels. Grade 3 is obtained by providing direct education to Canasoft Information System Services at Griya cell when providing an understanding of IT verbally.

8. In response to potential IT risks, efforts to maintain current business processes are considered when making sudden changes that may pose a potential greater IT risk.

\subsubsection{Data Analysis Data}

analysis has several steps that must be done. Aims to process data so that it can assist in decision making and research conclusions.

\subsubsection{Analysis of Current Capability}

Processing respondent data by performing calculations using the Guttman method to determine the value of the current capability level. The value of current capability level can be seen in Table 4:

\section{Table 4. Current APO12 Calculation Results}

Risk Management. The briefing is carried out to provide an understanding of IT Risk Management, which includes an assessment of level capability. The result of the delivery of this material is an agreement between the Manager and the Marketing Staff to set the desired value at level 3.

\subsubsection{Gap Analysis}

The gap is obtained from the calculation of the known capability value. The comparison between the current capability value and the desired capability value. It is known that in each domain APO12 has an average value of 2.60 and EDM03 has an average value of 2.58 while the desired capability value is at level 3 from the comparison results above, there is a Gap value of 1 level in each domain used. . gaps can be analyzed by comparing the findings of the questionnaire with the results of observations and interviews. The comparison will result in a counter statement where the reality and the respondent's questionnaire answers do not have proper synchronization.

\subsubsection{Assessment Results}

In this subsection, the known values will be presented. The results of the calculation of capability level value can be seen in Table 6 .

Table 6. Level Value Comparison APO12

\begin{tabular}{|l|l|c|c|c|c|}
\hline Domain & Process & Current & $\begin{array}{c}\text { Expe } \\
\text { cted }\end{array}$ & Max & Gap \\
\hline APO12.01 & $\begin{array}{l}\text { Collecting } \\
\text { Data }\end{array}$ & 2.70 & 3 & 5 & 1 \\
\hline APO12.02 & $\begin{array}{l}\text { Analyzing } \\
\text { Risk }\end{array}$ & 2.60 & 3 & 5 & 1 \\
\hline APO12.03 & $\begin{array}{l}\text { Maintaining } \\
\text { RiskProfile }\end{array}$ & 2.66 & 3 & 5 & 1 \\
\hline APO12.04 & $\begin{array}{l}\text { Articulate } \\
\text { Risk }\end{array}$ & 2.62 & 3 & 5 & 1 \\
\hline APO12.05 & $\begin{array}{l}\text { Lowers risk } \\
\text { impact }\end{array}$ & 2.72 & 3 & 5 & 1 \\
\hline APO12.06 & $\begin{array}{l}\text { Respond to } \\
\text { Risk }\end{array}$ & 2.29 & 3 & 5 & 1 \\
\hline
\end{tabular}

Based on Table 6 above, it can be concluded that Canasoft's Information System Service at Griya cell reached the level of 2 with a gap of level 1 in all existing domains. The known gap values will be reduced to be used as material for further investigations so that they can produce IT risk recommendations with the aim that Canasoft Information System Services in Griya cell can reach the desired level. Here are the results of the EDM03 comparison level value in Table 7: 
Table 7. LevelValue Comparison EDM03

\begin{tabular}{|c|l|c|c|c|c|}
\hline Domain & \multicolumn{1}{|c|}{ Process } & Current & $\begin{array}{c}\text { Expec } \\
\text { ted }\end{array}$ & Max & Gap \\
\hline EDM03.01 & $\begin{array}{l}\text { Evaluating } \\
\text { the Risk } \\
\text { Management }\end{array}$ & 2.58 & 3 & 5 & 1 \\
\hline EDM03.02 & $\begin{array}{l}\text { Directing } \\
\text { Risk } \\
\text { Management }\end{array}$ & $\mathbf{2 . 6 7}$ & $\mathbf{3}$ & $\mathbf{5}$ & $\mathbf{1}$ \\
\hline
\end{tabular}

Based on Table 7 above it can be concluded that the information system service Canasoft in Griya cell reaches level 2 with a gap value of level 1 in all existing domains. The value of the known gap will be reduced to be the subject of further investigation so that it can produce IT risk recommendations with the aim that Canasoft Information System Services in Griya cell can reach the desired level.

Level completeness assessment is the process of checking support needs to meet the requirements for level achievement in each APO12 and EDM03 domain. Following are the results of the examination of the needs of the fans Based on the results of the assessment that APO12 and EDM03 capability levels have reached level 2 on APO12 and EDM03 to be able to prove that human resources are valid, Griya cell must have complete data requirements at level 1 (performed process), level 2 (managed process). The following is the completeness of the required data that has been owned so that the Canasoft Information System Service at Griya cell by APO12 and EDM03 is at level 1 as shown in Table 8:

\section{Table 8. Completeness of Level 1 Data Processes} Performed

\begin{tabular}{|c|l|c|}
\hline \multicolumn{3}{|c|}{ PA 1.1 (Process Performed) } \\
\hline Domain & \multicolumn{1}{|c|}{ Goal } & Description \\
\hline APO12.01 & Collect data to analyze risk & $\boldsymbol{V}$ \\
\hline APO12.02 & $\begin{array}{l}\text { data analysis risk } \\
\text { Keep attributerisk }\end{array}$ & $\boldsymbol{V}$ \\
\hline APO12.03 & Keeprisk attributes & $\boldsymbol{V}$ \\
\hline APO12.04 & $\begin{array}{l}\text { provide opportunities for IT } \\
\text { risk } \\
\text { information }\end{array}$ & $\begin{array}{l}\text { Manage opportunities to } \\
\text { minimize the risk of }\end{array}$ \\
\hline APO12.05 & $\begin{array}{l}\text { Responding appropriately to IT } \\
\text { risk }\end{array}$ & $\boldsymbol{V}$ \\
\hline APO12.06 & $\begin{array}{l}\text { Evaluate and make an } \\
\text { assessment of the use of IT }\end{array}$ & $\boldsymbol{V}$ \\
\hline EDM03.01 & $\begin{array}{l}\text { Directs the implementation of } \\
\text { IT Risk management }\end{array}$ & $\boldsymbol{V}$ \\
\hline
\end{tabular}

Based on Table 8 completeness of data to achieve level 2 have all been met, in other words level 1 can be interpreted by the scale PA (process attributes) have attribute values $>85 \%$ $100 \% \mathrm{~F}$ (fully achieved). Furthermore, to be eligible at level 2 , Griya cell should have most complete data management and product management performance as shown in Table 9:
Table 9. Completeness Level 2 Data Managed Process on the Performance Management

\begin{tabular}{|l|l|c|c|}
\hline \multirow{2}{*}{$\begin{array}{c}\text { PA 2.1 (Performed } \\
\text { Management) }\end{array}$} & \multicolumn{1}{|c|}{ Evidence of } & \multicolumn{2}{c|}{$\begin{array}{c}\text { extensive } \\
\text { details }\end{array}$} \\
\cline { 3 - 4 } & $\begin{array}{c}\text { There } \\
\text { is }\end{array}$ & not \\
\hline $\begin{array}{l}\text { scope of the Risk } \\
\text { Management Risk }\end{array}$ & $\begin{array}{l}\text { report of sales daily } \\
\text { and report the stock } \\
\text { availability of goods } \\
\text { per day }\end{array}$ & $v$ & \\
\hline $\begin{array}{l}\text { Interest Risk } \\
\text { Management }\end{array}$ & $\begin{array}{l}\text { report of sales daily } \\
\text { and report the stock } \\
\text { availability of goods } \\
\text { per day }\end{array}$ & $\checkmark$ & \\
\hline $\begin{array}{l}\text { Response Griya } \\
\text { Cell if it does not } \\
\text { meet the target }\end{array}$ & - & & \\
\hline $\begin{array}{l}\text { RACI Chart } \\
\text { Management } \\
\text { Stakeholder }\end{array}$ & - & & \\
\hline
\end{tabular}

Based on Table 9 some supporting documents have not met performance APO12 (risk management) and EDM03. Thus at this stage with a rating of $\mathrm{P}$ (Partially Achievement) which means there is some evidence that exists and some of the achievements of the process attributes are assessed. Furthermore, the completeness of the Work Product table can be seen in Table 10 :

Table 10. Completeness of Managed Process Level 2 Data on the Work Product

\begin{tabular}{|l|l|c|c|}
\hline \multicolumn{1}{|c|}{$\begin{array}{c}\text { Goal Work } \\
\text { Product }\end{array}$} & \multicolumn{1}{c|}{ Evidence of } & \multicolumn{2}{c|}{ Mercy } \\
\cline { 2 - 4 } & Yes & No \\
\hline $\begin{array}{l}\text { List of work that } \\
\text { must be done by } \\
\text { each staff, admin } \\
\text { and store head } \\
\text { on the } \\
\text { information } \\
\text { system }\end{array}$ & $\begin{array}{l}\text { Results Report daily } \\
\text { and daily stock } \\
\text { availability reports }\end{array}$ & $\boldsymbol{V}$ & \\
\hline $\begin{array}{l}\text { Documents or } \\
\text { lists of work } \\
\text { needs that must } \\
\text { be completed by } \\
\text { each staff }\end{array}$ & Employee SOP & $\checkmark$ & \\
\hline $\begin{array}{l}\text { document } \\
\text { Documentation } \\
\text { of the work that } \\
\text { has been } \\
\text { completed by } \\
\text { each staff, admin } \\
\text { and store head } \\
\text { on the } \\
\text { information } \\
\text { system Canasoft }\end{array}$ & $\begin{array}{l}\text { Documents Employee } \\
\text { daily reports on } \\
\text { information system } \\
\text { services Canasoft }\end{array}$ & $\boldsymbol{V}$ & \\
\hline $\begin{array}{l}\text { Evaluation } \\
\text { ofwork } \\
\text { employee }\end{array}$ & $\begin{array}{l}\text { Document Daily } \\
\text { reports of employees } \\
\text { oninformation system } \\
\text { services. Canasoft }\end{array}$ & $\boldsymbol{V}$ & \\
\hline
\end{tabular}

Based on Table 10 above, the complete list of requirements in the APO12 and EDM03 domains to reach level 2 on the Work 
Product has been fully achieved. This if calculated using the capability level scale has an attribute value $>80-100 \%$ F (Full Archived). APO12 and EDM03 comparison chart can be found in Figure 5 and 6:

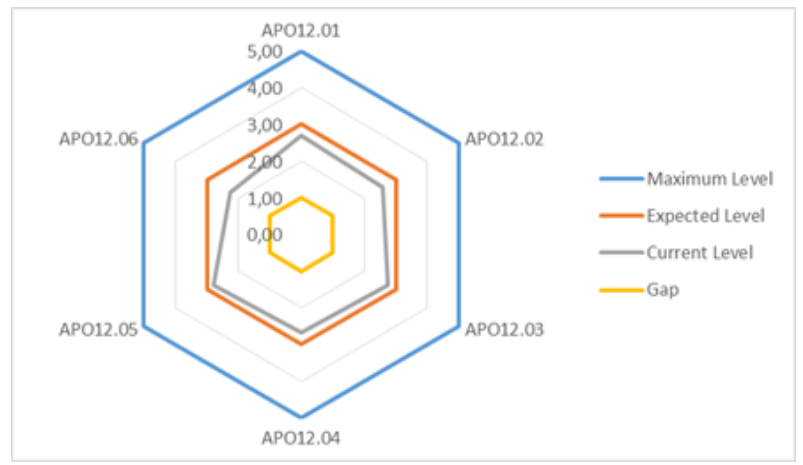

Figure 5. APO12 Comparison Chart

Figure 6 above, the complete list of requirements in the APO12 and EDM03 domains to reach level 2 on the Work Product has been fully achieved. This if calculated using the capability level scale has an attribute value $>80-100 \%$ F (Full Archived).

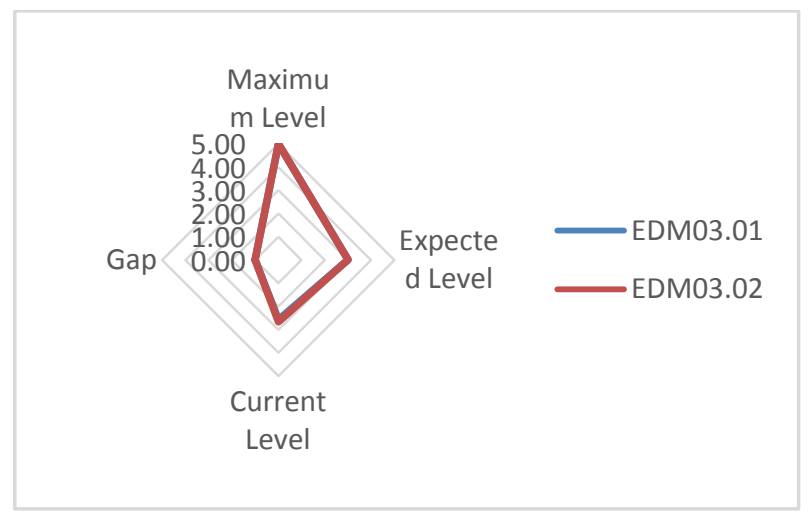

Figure 6. EDM03 Comparison Chart

Figure 6 above, the complete list of requirements in the APO12 and EDM03 domains to reach level 2 on the Work Product has been fully achieved. This if calculated using the capability level scale has an attribute value $>80-100 \%$ F (Full Archived).

graph presents valid data according to the assessment results.information system service Canasoft's at Griya cell has 1 gap value which is then followed up by making recommendations to be implemented until it reaches the desired level, which is 3 levels.

\subsubsection{Recommendations and Reporting Results}

At this stage the researcher makes recommendations based on domains that have Gap values. Recommendations in the form of suggestions and relevant directions so that they can be accepted and implemented by the information system service Canasoft at Griya. Implemented by Information systems Canasoft services at Griya to improve IT Risk Management. It should be noted that the findings of the questionnaire were obtained from respondents' answers which were accumulated into one based on the identity of each question from each level which was then compared with the results of observations and interviews. The results of the recapitulation of APO12 recommendations can be seen in Table 11:
Table 11.APO12 recommendations

\begin{tabular}{|c|c|c|}
\hline $\begin{array}{c}\text { Domain APO12 } \\
\text { (Risk } \\
\text { Management) }\end{array}$ & & Recommendation \\
\hline \multirow[t]{2}{*}{$\begin{array}{l}\text { APO12.01 } \\
\text { (collecting data) }\end{array}$} & & $\begin{array}{l}\text { Service information system Canasoft } \\
\text { in Griya cell must have a regular } \\
\text { schedule, either monthly or annually } \\
\text { related to this matter and must create } \\
\text { a risk group that distinguishes } \\
\text { between IT risks and general risks. } \\
\text { information system Canasoft services } \\
\text { in Griya cell should add the ideal IT } \\
\text { stafftobeabletoassistincarryingout } \\
\text { tasksand } \\
\text { information system Canasoft services } \\
\text { in Griya cell can increase the } \\
\text { utilization of the results of } \\
\text { documenting IT risk history. } \\
\text { Theinformation system service } \\
\text { Canasoft at Griya cell should } \\
\text { documentanyrisksthathaveoccurred } \\
\text { so that they can be used as evaluation } \\
\text { material to avoid the same IT risk } \\
\text { from happening }\end{array}$ \\
\hline & & $\begin{array}{l}\text { Documentation is physical, such as in } \\
\text { the form of soft files or hard files. } \\
\text { Before starting a new business } \\
\text { process,Information System Services } \\
\text { Canasoft at Griya cell need to do } \\
\text { careful planning including assessing } \\
\text { IT risks that occur, while for business } \\
\text { processes that are already running } \\
\text { Information System Services } \\
\text { Canasoft must carry out joint } \\
\text { evaluations. } \\
\text { Griya Leaders Need to add staff or } \\
\text { special fields that are closely related } \\
\text { to IT risk analysis, so that all types of } \\
\text { risks can be immediately known }\end{array}$ \\
\hline $\begin{array}{l}\text { APO12.02 } \\
\text { (analyzing risk) }\end{array}$ & 3 & $\begin{array}{l}\text { In the training materials Information } \\
\text { System Services Canasoft at Griya } \\
\text { cellshouldincludediscussionsrelated } \\
\text { to risks, both IT and general. So that } \\
\text { elements who receive training can } \\
\text { understand actions that have the } \\
\text { potential to cause assetlosses. } \\
\text { In cases related to the use of } \\
\text { IT,Information System Services } \\
\text { Canasoft in Griya cell should make } \\
\text { improvements to the IT governance } \\
\text { sector including riskmanagement. } \\
\text { information system Canasoft services } \\
\text { at Griya cell should have objective } \\
\text { standards related to IT risk, it is } \\
\text { necessarytocarryoutriskmappingso } \\
\text { that it can be used as a standard value } \\
\text { in measuring the level of riskimpact, } \\
\text { in order to assist in making decisions }\end{array}$ \\
\hline
\end{tabular}




\begin{tabular}{|c|c|}
\hline $\begin{array}{l}\text { APO12.03 } \\
\text { (maintaining } \\
\quad \text { risk profile) }\end{array}$ & $\begin{array}{l}\text { 1. information system Canasoft } \\
\text { services in Griya cell should have a } \\
\text { concept that describes how IT risks } \\
\text { will appear in the future, so that } \\
\text { when a risk arises, Griya cell is } \\
\text { ready, of course, with stakeholders } \\
\text { who are responsible for responding } \\
\text { to risks and daring to make } \\
\text { decisions. } \\
\text { information system Canasoft } \\
\text { services in Griya cell should have } \\
\text { indicators of success in achieving a } \\
\text { business process related to IT risk. } \\
\text { Including indicators of business } \\
\text { success in sales and finalstock }\end{array}$ \\
\hline $\begin{array}{l}\text { APO12.04 } \\
\text { (articulate risk) }\end{array}$ & $\begin{array}{ll}1 . & \text { information system Canasoft } \\
\text { services in Griya cell should have } \\
\text { relationships with external parties } \\
\text { such as staff In addition to being a } \\
\text { supporting actor, IT also needs tobe } \\
\text { an assessing actor for Information } \\
\text { System Services Canasoft } \\
\text { Assessment including IT } \\
\text { performance andrisk. } \\
\text { 2. information system Canasoft' } \\
\text { services at Griya cell should make } \\
\text { SOPs for managing IT-related } \\
\text { business processes, including } \\
\text { determining when an actor is } \\
\text { required to analyze gaps that may } \\
\text { cause biglosses. }\end{array}$ \\
\hline $\begin{array}{l}\text { APO12.05 } \\
\text { (reducing the impact } \\
\text { of risk to an } \\
\text { acceptable level by } \\
\text { the } \\
\text { portfolio/tolerance } \\
\text { value) }\end{array}$ & $\begin{array}{l}\text { 1. Information system service } \\
\text { canasoft at Griya cell should have an } \\
\text { AD/ART manifesto on the potential } \\
\text { for IT risks caused by actors as well } \\
\text { asadailyavailabilityreportstoredin the } \\
\text { databasecanasoft }\end{array}$ \\
\hline $\begin{array}{l}\text { APO12.06 ( respond } \\
\text { to risk) }\end{array}$ & $\begin{array}{l}\text { 1. informationsystemserviceCanasoft } \\
\text { at Griya cell should have by adding } \\
\text { a competent person in the IT risk } \\
\text { analysissection. } \\
\text { 2. In supporting all businessprocesses, } \\
\text { Information System Canasoft } \\
\text { Services in Griya the cell should } \\
\text { have an grouping of inputsand } \\
\text { outputs all-encompassing. }\end{array}$ \\
\hline
\end{tabular}

Based on Table 11 the recapitulation of recommendations from the APO12 domain that has been made must be implemented by Information System Services Canasoft in Griya cell with the aim of minimizing the impact of IT risk, .It should be noted that the findings of the questionnaire were obtained from respondents' answers which were accumulated into one based on the identity of each question from each level then compared with the results of observations and interviews. The following are the results of the recapitulation of the EDM03 domain recommendations seen in Table 12: basis. Based on Table 12, the recapitulation of recommendations from the EDM03 domain that has been made must be implemented, supervised byInformation System Services Canasoft in Griya cell with the aim of minimize the impact of IT risks.

\section{Table 12. EDM03 recommendations}

\begin{tabular}{|l|l|}
\hline $\begin{array}{c}\text { Domain EDM03 } \\
\text { (Risk Optimization) }\end{array}$ & \multicolumn{1}{|c|}{ Recommendations } \\
\hline $\begin{array}{l}\text { EDM03.01 (evaluating risk } \\
\text { management) }\end{array}$ & $\begin{array}{l}\text { 1. information system Canasoft services at } \\
\text { Griya cell information system Canasoft } \\
\text { services at Griya cell are recommended } \\
\text { to make a report on decisions to deal } \\
\text { with IT risk limits that will occur, in } \\
\text { order to anticipate futurerisks. } \\
\text { 2.information system service Canasoft in } \\
\text { Griya cell is recommended to make a } \\
\text { risk management evaluation reportin } \\
\text { order to anticipate the occurrence of risk }\end{array}$ \\
\hline $\begin{array}{l}\text { EDM03.02 (direct } \\
\text { riskmanagement) }\end{array}$ & $\begin{array}{l}\text { 1.information system service Canasoft in } \\
\text { Griya cell is recommended to make a } \\
\text { report to assess risk optimization } \\
\text { performance in order to anticipate the } \\
\text { occurrenceofrisk } \\
\text { 2. system service information Canasoft in } \\
\text { the Griya cell is recommended to } \\
\text { monitor by collecting reports andasking } \\
\text { the admin to check the availability of } \\
\text { goods on a daily }\end{array}$ \\
\hline
\end{tabular}

\section{CONCLUSION}

Based on the results of research on the APO12 (Risk Management) domainvalue Capability Level, which has aof 2.60 which means that at this level the implementation of business processes at the Information System Service Canasoft at Griya cell has carried out planning, monitoring and adjustment and the work results have been determined, observed and maintained properly and based on research results in the EDM03 (Risk Optimization) domain, which has avalue Capability Level of 2.58 which means that at this level the implementation of business processes at Information System Services Canasoft at Griya cell has carried out planning, monitoring and adjustments as well as the results its work has been determined, evaluated and maintained properly. The value of the Gap on APO12 (Risk Management) and EDM013 has been known according to a concrete calculation by obtaining avalue Gap of 1 level, which means that a recommendation is needed to reach the desired level. Information Canasoft'steam at Griya cell must have a regular schedule, either daily, monthly or yearly, create SOPs on IT risk management based on evaluation results, document risk history, plan before starting business processes and update IT scenarios.

\section{REFERENCES}

[1] Soejanto, Joshua, and Andi Reza Perdanakusuma. 2018. "Evaluation of Information Technology Governance at PT. Aerofood Indonesia Soekarno Hatta Airport Cengkareng By Using."Journal of Information Technology Development and Computer Science (JPTIIK) Universitas Brawijaya 2 (11): 4714-21.

[2] Arief, M Habibullah. 2018. "Evaluation of Information Technology Risk Management Using the COBIT 5 Framework (Case Study at Perum Jasa Tirta I Malang)." Journal of Information Technology Development and Computer Science 2.

[3] Setyaningrum, Novia Dwi, Suprapto, and Ari Kusyanti. 2018. "Evaluation of Information Technology Risk Management Using the COBIT 5 Framework (Case 
Study: PT. Kimia Farma (Persero) Tbk - Watudakon Plant)." Journal of Information Technology and Computer Science Development 2 (1): 143-52.

[4] Megawati, and Syntia Ana. 2018. "Evaluation of Information Technology Risk Management Using the COBIT 5 Framework." Scientific Journal of Information Systems Engineering and Management 4 (2): 118-22.

[5] Firdaus, Nurfitri Zukhrufatul. 2018. "Evaluation of Information Technology Risk Management Using COBIT 5 IT Risk (Case Study: PT. Petrokimia Gresik)." Journal of Information Technology Development and Computer Science 2 (1): 91-100.

[6] Nanda Putra Wandita. 2014. "Evaluation of Information Technology Governance in Distance Education Systems Using the COBIT 5 Framework (Case Study: College of Police Science-Police Science College." Syarif Hidayatullah State Islamic University, Jakarta.

[7] ISACA. 2012a. Trust And Partnership A Business Framework for the Governance and Management of Enterprise IT.

[8] ISACA. 2012b. "COBIT 5.0. 2012. Main Framework Version 2.0.

[9] ISACA. 2012c. Isaca COBIT 5 Implementation.

[10] Arikunto, S. 2010. Research Procedures A Practical Approach. Rineka Cipta.

[11] ITGI.IT Governance institute. 2007.COBIT 4.1.IT Governance Institute.

[12] Jogiyanto, A. 2011. Information Technology Governance
System. Publisher Andi.

[13] Prof. Dr. Sugiyono. 2019. Qualitative and Quantitative Research Methods and R \& DM Dr. Ir. Sutopo.S.Pd (ed.); 1st d. ALFABETA, cv, Jalan Gegerkalong Hilir No. 84 .

[14] Putri,CU 2017. Risk Assessment of Informatio n Technology Processes Based on the COBIT 5 Framework in the Helpdesk of the Sub-Directorate of Technology Services and Information Systems, Directorate of Information Technology and Information Systems Development (DPTSI) Sepuluh Institute of Technology. 241.

[15] S.Gondodiyoto. 2007. The Information Systems Audit and COBIT Approach.

[16] Stewart, James M,:Chapple,Mike;Gibson,D. 2015.CISSP (ISC)2 Certified Information Systems Security Professional Official Study Guide, 7th Edition.Wiley

[17] Surendro, K. 2009.Implementation of Information Technology Governance, Information Technology

[18] Yunanda. $2009 . \quad$ Evaluation. http://repository.usu.ac.id/bits ream/ 123456789 /19622/4/Chapter II.pdf

[19] Fuad, MN (2020). Risk Management Assessment in UAD HR Information Technology Services Using the COIT 5 Method.

[20] Aziz, RA, Kusrini, \& Sudarmawan. (2018). Evaluation of Information Technology Risk Management in StateOwned Enterprises Using COBIT 5 Standard (Case Study: PT TASPEN PERSERO). CIDA IT Journal, 4(2). 